\title{
The protein quality of meat meals as assayed with the rat and with Streptococcus zymogenes
}

\author{
By R. FERRANDO, NICOLE HENRY AND P. LARVOR \\ Ecole Nationale Vétérinaire d'Alfort, Seine, France \\ (Received 1о fuly 1967-Accepted I4 August 1967)
}

\begin{abstract}
I. Seven samples of meat meal have been assayed with rats by the protein efficiency ratio (PER) test and with Streptococcus zymogenes by Ford's (I960) 'relative nutritive value' (RNV) test.

2. A correlation coefficient of $r=+0.895$ was obtained for the results from the two series of tests.
\end{abstract}

With the aim of finding whether the in vitro microbiological test of Ford (1960) could be used to assess the nutritional value of the protein in meat meals processed in different ways, we have investigated seventeen samples, using both a microbiological method and a measure of protein efficiency ratio (PER) determined with the rat. This is an extension of our earlier study with fish meals (Ferrando, Henry \& Constantin, 1965).

\section{EXPERIMENTAL}

The meat meals investigated had been submitted to various thermal and chemical treatments as set out in Table $\mathbf{1}$. Difco casein was used as the standard in the microbiological tests.

Male albino rats of the Wistar strain from our own colony, weighing about $40 \mathrm{~g}$, were housed in individual cages for 28 days. The experimental diets each contained sufficient of the test protein source to contribute $13 \%$ crude protein, $2 \%$ arachis oil, $3 \%$ vitamin-and-mineral mixture and sucrose $a d 100$. Nine rats were allocated to each diet. The rats were weighed twice a week and feed consumption was measured every day. Water was given 'ad lib.' PER was calculated as:

$$
\frac{\text { gain in weight }(\mathrm{g})}{\text { protein intake }(\mathrm{g})} \text {. }
$$

The relative nutritive value (RNV) of the samples was estimated according to Ford (1960), using Streptococcus zymogenes.

\section{RESULTS AND DISCUSSION}

The results are set out in Table I. Fig. I, a scatter diagram, shows a correlation between the PER values measured in the rat and the microbiological RNV results. Since the relationship is not linear, we have plotted the PER on a logarithmic scale. (PER values around zero were considered as equal to 0.1 in order to be able to calculate the corresponding logarithm.)

The coefficient of correlation between the two sets of results expressed in this way 
was: $r=+0.895$. This was statistically highly significant. The regression equation relating the PER values to the RNV values can be expressed by the following formula:

$$
\log (\mathrm{TO} \times \mathrm{PER})=0.018 \mathrm{RNV}-0.64 \text {. }
$$

It is thus possible to calculate, for a given value of RNv, the most probable corresponding value for the PER as it would arise from measurement in the rat. In such conditions, the coefficient of variation of indirect determination of the protein efficiency is approximately $\pm 20 \%$.

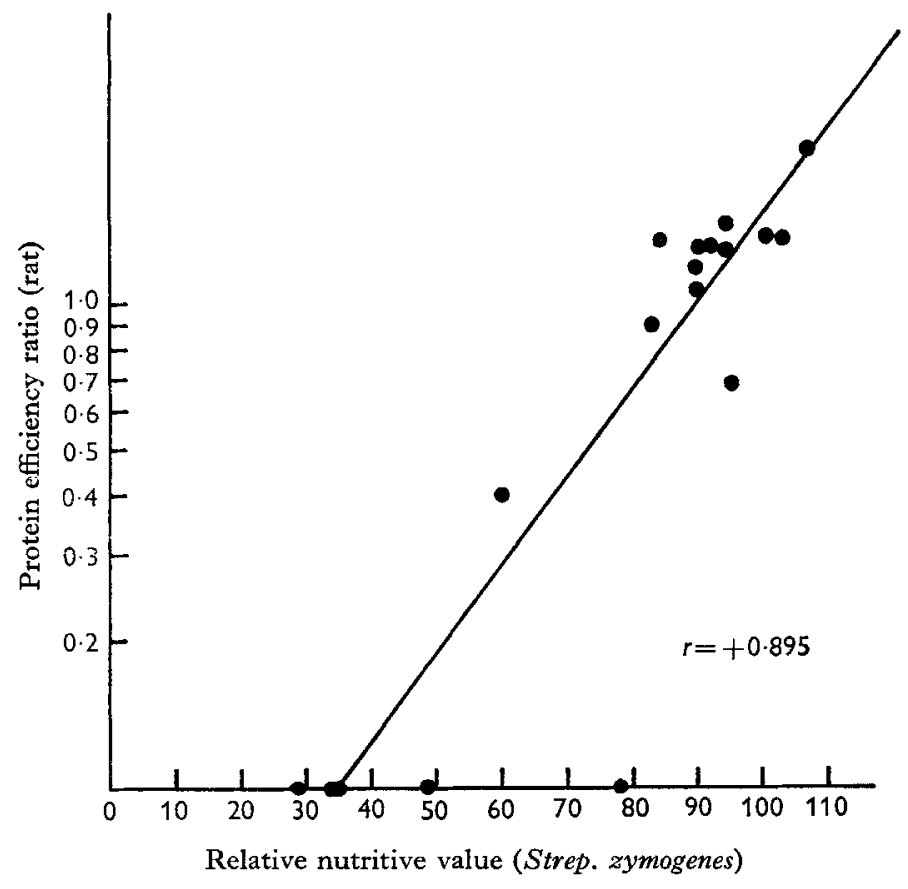

Fig. I. Relationship between 'relative nutritive value' (Streptococcus zymogenes) and protein efficiency ratio (rat) of seventeen meat meals. The solid line represents the regression equation $\log (10 \times \mathrm{PER})=0.018 \mathrm{RNV}-0.64$.

The relationships between the two methods seemed acceptable except for three further test materials not included in Table $\mathbf{I}$. These we discarded from our series, as the flesh from which they came had remained several days in denaturalized alcohol or in an ammonia atmosphere. These meat meals had an acceptable RNV of approximately 80 , but in the rat their protein efficiency was nil. 
Table I. Treatments used in producing meat meals and their values in two protein quality tests

Sample code F FG $528-64$ $529-64$ $53 \mathrm{I}-64$ $533-64$

Meal 500 gro-64 9 I $1-64$ $950-64$

$\mathrm{x}-6_{5}$ *

2-65*

$3-65 *$

$4^{-6} 5^{*}$

$5-65$

$6-65$
$7-65$

\section{Method of preparation}

Fillet dried at $90^{\circ}, 24 \mathrm{~h}$

Fillet $+15 \%$ D-glucosamine

Meat meal: average grade dried at $70^{\circ}, 24 \mathrm{~h}$ treated with $2 \mathrm{~N}-\mathrm{HCl}$ and dried at $70^{\circ}, 24 \mathrm{~h}$ treated with $2 \mathrm{~N}-\mathrm{HCl}$ and dried at $70^{\circ}, 24 \mathrm{~h}$ treated with $2 \mathrm{~N}-\mathrm{HCl}$ and dried at $70^{\circ}, 24 \mathrm{~h}$

Commercial French meat meal dried at $130^{\circ}, 3 \mathrm{~h}$

Meat meal: treated with $2 \mathrm{~N}-\mathrm{HCl}$ and dried at $70^{\circ}, 24 \mathrm{~h}$ treated with $2 \mathrm{~N}-\mathrm{HCl}$ and dried at $130^{\circ}, \mathrm{I} \mathrm{h}$ treated with $0.05 \mathrm{~N}-\mathrm{NaOH}$ and dried at $70^{\circ}$, $24 \mathrm{~h}$

first quality dried at $80^{\circ}, \mathrm{I} \mathrm{h}$

without tendons dried at $130^{\circ}$, I h

second quality with more collagen than $1-65$, dried at $70^{\circ}, 24 \mathrm{~h}$ second quality with more collagen than $I-65$, dried at $130^{\circ}, \mathrm{rh}$

Tendon meal, rich in collagen, dried at $100^{\circ}, \mathrm{I} \mathrm{h}$

Elastin and collagen meal, dried at $130^{\circ}, \mathrm{I} \mathrm{h}$

Elastin treated with $2 \mathrm{~N}-\mathrm{HCl}$ and dried at $130^{\circ}$, I h

\begin{tabular}{|c|c|}
\hline $\begin{array}{l}\text { Protein } \\
\text { efficiency } \\
\text { ratio } \\
\text { determined } \\
\text { in the } \\
\text { rat }\end{array}$ & $\begin{array}{c}\text { Relative } \\
\text { nutritive } \\
\text { value } \\
\text { (Streptococcus } \\
\text { zymogenes) }\end{array}$ \\
\hline $2 \cdot 10$ & $107 \cdot 4$ \\
\hline 0.67 & $95 \cdot 6$ \\
\hline 0.40 & 60.3 \\
\hline$x \cdot 09$ & 90.0 \\
\hline I. 38 & 102.7 \\
\hline$I \cdot 32$ & $90 \cdot 1$ \\
\hline 0.10 & $48 \cdot 4$ \\
\hline $1 \cdot 38$ & 8377 \\
\hline$I \cdot 47$ & 93.5 \\
\hline 0.10 & $77 \cdot 9$ \\
\hline $\mathrm{I} \cdot 40$ & 100.5 \\
\hline$I \cdot 20$ & 89.5 \\
\hline$I \cdot 30$ & $94^{\circ} 0$ \\
\hline 0.90 & $82 \cdot 6$ \\
\hline 0.10 & $35^{\cdot I}$ \\
\hline 0.10 & 34.5 \\
\hline 0.10 & 29.0 \\
\hline
\end{tabular}

* Hydroxyprolin content $(\%)$ in $\mathrm{I}-65=3.53,2-65=3.47,3-65=3.69,4-65=3.88$.

\section{REFERENCES}

Ford, J. E. (1960). Br. F. Nutr. 14, 485 .

Ferrando, R., Henry, N. \& Constantin, J. L. (1965). Recl Méd. vét. Éc. Alfort I4r, I37. 